$$
\begin{gathered}
\text { 항공사 기내서비스품질, 고객가치, 관계유지의도의 영향 관계 } \\
\text {-상위클래스 이용 승객을 대상으로- }
\end{gathered}
$$

\title{
A Study on the Effect Between Cabin Service Quality, Customer Value and Relationship Retention Intention in Airline -Focus on the upper-class seats customers-
}

\author{
윤선영* \\ Sun-Young Yoon ${ }^{*}$ \\ 요 약
}

본 연구는 항공기 상위클래스를 이용하는 고객의 기내서비스에 대한 서비스품질과 고객가치 및 관계유지의 도와의 영향 관계를 규명하고자 함에 목적이 있다. 이를 위해 기내서비스품질을 물적 서비스품질과 인적 서비 스품질요인으로 선정하였고 고객가치를 매개변수로 종속변수인 관계유지의도간의 인과관계를 나타내는 연구모 형과 연구가설을 설정하였다. 분석결과, 항공기 상위클래스 물적 서비스품질요인과 인적 서비스품질요인 모두 고객가치와 관계유지의도에 유의한 정 $(+)$ 의 영향을 미치는 것으로 나타났으며 상위클래스 서비스품질에 대한 고객의 가치는 관계유지의도에 정 $(+)$ 의 유의한 영향을 미치는 것으로 나타나 해당 항공사와 지속적인 관계를 유지할 가능성이 높은 것으로 나타났다. 이러한 연구결과에 의해 항공기 상위클래스를 이용하는 상용고객의 로 열티 확보와 선호도 등을 파악하여 고객이 특별함을 느끼게 하는 서비스전략이 필요하며 항공사는 조직의 내 부점검과 고객감동의 가치실현을 위해 승무원 서비스교육에 투자와 정성이 요구된다.

\section{Abstract}

The purpose this study is to find out how cabin service quality influences customer value and relationship retention intention focus on upper-class seats customer in airline.

In the result of the hypothesis verification, this study hypotheses concerning the effect relations between cabin service quality, customer value and relationship retention intention. Therefore this study needs to be studied the quality of cabin service of upper-class and service value. Based on the research findings airline cabin service department have to examine various customer needs with the development of items and services.

Key words : Upper- class, Cabin service quality, Customer value, Relationship retention intention

\section{I. 서 론}

항공업계는 유가상승 및 저렴한 가격을 제공하는
다양한 저가항공사의 등장과 세계 경제침체 및 신종 질병까지 여러 악조건적인 상황을 극복하기 위해 새 로운 경영전략을 통한 마케팅이 요구되고 있는 실정

*경기대학교 관광대학 이벤트학과 부교수

· 제1저자 (First Author) : 윤선영

· 투고일자 : 2012년 3월 5일

· 심사(수정)일자 : 2012년 3월 7일 (수정일자 : 2012년 4월 26일)

· 게재일자 : 2012년 4월 30일 
이다. 또한 고객은 점차 개인의 가치를 집중하여 획 일적이고 표준화된 서비스보다는 개인의 개성 및 욕 구에 적합한 차별적인 대우와 환대를 받기 원하고 있 으며 이는 소비패턴에 있어서의 양극화 현상과 값이 비싸더라도 우수한 품질이나 감성적인 만족을 위해 서 고가의 상품을 선택하는 경향을 보이고 있다. 최 근 벌어지고 있는 항공사간의 서비스 경쟁 또한 고급 화를 지향하고 있는 것이다.

현재 전 세계적으로 대부분의 항공사들이 상위클 래스에 보다 많은 공간을 확보하고 더 나은 서비스를 위한 새로운 기준을 도입하고 있으며 몇몇 항공사들 은 일반석을 없애고 수익성 좋은 상위클래스 좌석을 확대하고 있다.

실제로 독일 루프트한자와 에어프랑스 항공사는 우량고객 중심전략인 '고가(高價) 마케팅'에 동참하 고 있다[12]. 상위클래스 이용고객이 전체 고객에서 차지하는 숫자는 $8 \%$ 밖에 되지 않지만 매출액은 $20 \%$ 이상을 차지한다. 전 세계 항공사들이 수익성 제고를 위해 상위클래스에 대한 투자를 대폭 강화하고 있는 것이다.

또한 대한항공은 동북아 공사로는 최초로 $\mathrm{A} 380$ 차세대 항공기를 도입하여 대한항공의 프리미엄 전 략에 힘입어 평균 탑승율 $90 \%$ 이상을 기록하고 있다. $\mathrm{A} 380$ 항공기는 여유있는 프레스티지 공간과 독창적 인 기내면세품 전시 공간 등 마케팅을 강화하고 있다 [15]

고비용을 지불하며 지속적인 소비패턴을 보이는 상위클래스 고객은 항공사에 있어서 매우 매력적인 집단이며 항공사 이윤의 극대화와 직결되어 있어 상 위클래스 시장의 중요성이 점차 커지고 있다. 따라서 항공사의 수익을 위해 중요한 상위클래스 고객들에 대한 차별화된 서비스 개발이 매우 중요하며 양질의 고객을 지속적으로 확보하기 위한 방법 모색과 상용 고객유치, 고객과의 관계 형성을 잘 할 수 있는 마케 팅 전략수립이 절실하다고 할 수 있다.

본 연구는 항공사간의 경쟁이 날로 치열해져가고 있는 상황에서 살아남아야 하는 국내 항공사들이 고 수익을 창출할 수 있는 마케팅은 상위클래스 좌석 판 매이며 상위클래스를 이용하는 고객들의 욕구를 파 악하여 고객들의 가치에 따른 관계유지의도에 미치
는 영향을 검정하는데 그 의의가 있다. 이에 따라 고 객만족 서비스를 위한 발전전략을 수립하는데 유용 한 정보를 제공하고자 하며 또한 항공사의 매출향상 과 시장점유율 확보 및 대 고객 서비스 강화 및 경쟁 력 강화에 도움이 되고자 한다.

\section{II. 이론적 배경}

\section{2-1. 상위클래스}

항공기의 좌석등급은 보통 이코노미 클래스 (economy class), 비즈니스 클래스(business class), 퍼스 트 클래스(first class)로 구분되기도 하지만 서비스 절 차에 따라 일반석(이코노미 클래스)과 상위클래스(비 즈니스 클래스, 퍼스트 클래스)로 구분되어 지며[6] 항공사의 기준에 따라 클래스가 다르게 불려지기도 한다. 아시아나항공의 경우, 일반석(트래블 클래스), 상위클래스(비즈니스 클래스, 퍼스트 클래스)로 운영 되고 있다. 또한 아시아나 항공은 최근 신개념 비즈 니스 클래스 고품격시트인 오즈 쿼드라 스마티움 $(\mathrm{Oz}$ Quadra Smartium)을 B777기종에 장착하여 상위클래 스 고객들에게 선보이고 있다.

대한항공의 경우, 일반석(이코노미 클래스)과 상 위클래스(프레스티지 클래스, 일등석 코스모스위트, 코스모 슬리퍼시트)로 구분된다. 특히 일등석 코스모 는 VIP의 품격에 어울리는 최상의 좌석을 제공함과 동시에 프라이버시를 지켜주는 독립된 공간을 제공 한다(각 항공사 홈페이지 참고)

좌석등급이 세 가지로 나뉜 것은 1980년대부터 이 다. 세계를 누비는 비즈니스 고객을 잡기 위해 일반 석과 일등석 중간 단계인 비즈니스 클래스가 처음 등 장한 것이다. 2000 년대 들어서면서는 네 가지 좌석 등급 시대가 열렸다. 영국항공이 일반석과 비즈니스 클래스의 중간단계인 월드 트래블러 클래스를 선보 였고 대한항공도 일부 장거리 노선에 일등석 중의 일 등석으로 불리는 프리미엄 퍼스트 클래스를 만들었 다[9].

상위클래스에서 제공되는 서비스의 특징은 엔터 테인먼트의 경우 AVOD(Audio Video On Demand)인 
데 20가지 이상의 채널로 탑승객이 원하는 시간에 해 당 언어로 원하는 음악과 영화를 보고 들을 수 있는 시스템으로 개인 좌석에 장착이 되어 있어 언제든지 사용할 수 있는 장점이 있다. 또한 위성전화, 초고속 무선 인터넷 서비스를 이용할 수 있으며 공항에서의 라운지 이용, 기내식 또한 일반석과는 다른 다양하고 고급화된 메뉴를 선택할 수 있다.

\section{2-2. 기내서비스의 개념과 서비스품질 측정}

항공운송사업에 있어서 서비스의 초점은 기내에 서의 서비스로 집중된다. 기내서비스는 고객이 항공 사를 선택하는데 우선적으로 고려하는 요인 중의 하 나이며 고객이 항공사를 이용하면서 가장 접하는 시 간이 길고 항공운송서비스를 마무리하는 단계로 고 객의 만족, 불만족에 대한 지각에 미치는 영향력이 가장 큰 서비스이다[5]. 또한 기내서비스는 고객이 보다 쾌적하고 안전하게 여행할 수 있도록 고객의 다 양한 욕구만족을 위한 각종 시설물과 서비스 물품을 제공하는 물리적 서비스와 기내승무원들에 의해 수 행되는 인적 서비스가 결합되어 이루어진다.

오주희(2002)는 기내서비스를 물적서비스와 인적 서비스, 부가서비스로 구성하였고 한정혜(2004)는 물 적서비스, 인적서비스, 소프트웨어서비스로 나누었 다. 과거에는 주로 물적서비스에 치중되었으나 점차 적으로 고객들의 욕구가 점점 높아지고 다양해짐에 따라 항공사간 경쟁이 치열해지면서 기내 물적서비 스 요소뿐만 아니라 인적서비스가 더욱 강조되고 있 는 실정이다. 따라서 항공사는 어느 한 부분에 치중 하기보다는 균형 있고 향상된 서비스를 지속적으로 제공하여 고객의 편의를 도모하고 서비스 경쟁력을 확보해 나가야 한다[7][11].

서비스품질에 대한 기존 연구는 Parasuraman, Zeithaml \& Berry $(1985,1988)$ 의 SERVQUAL 즉, 서 비스품질을 구성하는 5 가지 차원(유형성, 신뢰성, 확 신성, 공감성, 확신성)을 바탕으로 측정되어졌다. 또 한 Cronin \& Tayler(1992)은 PZB(1985,1988)의 이러한 $\mathrm{SEVQUAL}$ 의 모형이 여러 산업분야에 적용되고 있지 만, 사전기대와 실제성과를 객관적으로 측정하는 것 이 어렵다고 판단하여 SEVPERF모형을 제안하였지
만, 많은 관련 연구들이 이러한 두 가지 모형을 혼합 하여 사용하고 있다[22][23].

항공사 서비스의 품질 결정요인은 $\mathrm{PZB}$ 에 의해 연 구되어진 서비스품질 결정요인을 정익준(1992)이 재 구성하였으며 이 요인들은 다시 5 가지 차원(유형성, 신뢰성, 반응성, 확실성, 감정이입)으로 분류되어진 다[8].

김경숙(1996)은 항공 선택 속성별 중요도와 만족 도를 중심으로 경영성과와의 관계를 규명하기 위해 서비스품질을 요인 분석한 결과 8 가지 요인(신속하 고 친절한 예약 및 기내서비스, 부대서비스의 다양 성, 기내 소모품 및 식음료 서비스, 항공사의 명성 및 이미지, 항공편 연결의 편리성 및 정시성, 항공권 수 하물의 운인, 자국승무원 및 안전요원의 탑승서비스) 을 도출하였다.

Liou와 Tzeng(2007)은 항공사 서비스를 인적서비 스, 안전성과 신뢰성, 기내서비스, 스케줄, 정시성, 상 용고객우대제도 등의 6가지 요인으로 분류하여 국제 선 항공을 이용하는 고객을 대상으로 항공서비스품 질에 관한 평가를 하였다[19].

이들의 연구를 종합하여 본 연구에서의 상위클래 스 서비스품질요인을 물적 서비스품질요인과 인적 서비스품질요인으로 구분하였으며 서비스품질 측정 도구로서 $\mathrm{PZB}(1988)$ 의 서비스품질 항목과 정익준 (1992)의 연구에서 5 가지 품질요인을 본 연구에 맞게 응용하였다[8].

\section{2-3. 고객가치}

지각된 고객가치에 대한 연구는 많은 학자들에 의 해 진행되어 왔으나 가치가 주는 의미는 사람마다 다 르고 측정 또한 어렵다는 것이 일반적인 견해이다. 그리고 연구 목적과 연구 대상에 따라 다소 차이가 있을 수 있는데 대체적으로 지각된 편익과 비용의 결 과로 정의된다. 비용은 물질적 비용과 시간, 우선권 의 상실, 그리고 경제적 상실 등과 같은 비물질적 비 용으로 구분될 수 있으며, 편익은 물질 모형에서의 품질에 대한 기대와 관련되는 것으로 기대일치/불일 치 개념으로 인식된다. 따라서 고객가치란 고객이 주 고받는 서비스효용에 대한 전반적인 평가와 기대불 
일치와 관련성을 의미하게 된다(Bieger et, al, 2007). 또한 소비자의 지각에 근거하여 제품이나 서비스효 용에 대한 평가라고 할 수 있으며 전반적인 서비스품 질에 대비 지불한 가격으로서 서비스 가치의 비교 관 점으로 접근할 수 있다(Lee, Yoon \& Lee, 2007).

초기의 관련 연구들을 살펴보면, 고객가치가 단일 차원요인으로써 연구범위가 많이 한정되었지만 (Bolton \& Drew, 1991; Dodds et, al, 1991; McCleary et, $\mathrm{al}, 2006)$, 점차적으로 연구대상이나 연구목적에 따라 다차원적 차원에서 새로운 변수들이 추출되었다([4].

Petrick(2002)은 관광산업에서의 고객의 가치를 5 가지 차원인 행동적인 가치, 금전적인 가치, 품질, 감 정적인 가치, 명성 등으로 개발하여 이들이 서비스 경험과 재이용 및 구전과 유의한 관계를 가진다고 하 였다[24].

또한 Korda \& Milfelner(2009)의 연구에서는 호텔 산업을 대상으로 인식가치(호텔에 머물고 있는 가치, 많은 지식의 경험, 머물고 있는 화폐가치), 감정적인 가치(호텔에 대한 좋은 느낌, 즐거움 등) 고객가치(이 유있는 가격가치, 추가적인 가격가치) 등 총 8 개를 고객가치변수로 추출하였으며 고객만족과 충성도에 가장 중요한 영향을 미치는 측겅변수를 고객가치로 꼽았다[18].

고객의 가치는 마케팅활동의 기본적인 토대이며 높은 가치는 기업에 대한 고객의 후원과 애호 및 장 려에 대한 동기를 유발시킨다.

이들의 연구를 종합하여 본 연구에서 고객의 가치 란 고객이 항공사 상위클래스 물적·인적서비스를 이 용하면서 지불비용에 대한 가치, 지속적인 높은 서비 스가치, 상징적 가치로 측정하고자 한다.

\section{2-4. 관계유지의도}

관계마케팅에서 기업의 마케팅 성과에 대한 척도 로 사용되고 있는 관계유지의도(relationship iretention intention)에 대해서 Berry \& Parasuraman(1996)은 상호 의존성을 전제로 하며 일단 거래를 통해 만족을 느낀 고객이 더 큰 만족을 느끼기 위해 거래 관계를 더욱 강화하고자 하는 의도라고 하였다. 그러므로 단기적 거래를 지향하는 고객은 현재의 선택과 결과에만 관
심을 가지는 반면 장기적 거래를 지향하는 고객은 현 재는 물론 미래의 결과에도 관심을 갖는다고 할 수 있다. 이와 같은 맥락에서 한상린(2004)은 관계유지 의도가 고객만족의 결과로서 나타나는 반응이라고 하였으며 이것은 고객이 서비스를 제공받고 난 뒤 앞 으로 다시 그 서비스를 찾으려고 하는 행위라고 주장 하였다[10]. 또한 Kumar, Bohling \& Ladda(2003)는 기 업과 고객의 관계에서 관계유지의도가 높으면 유지 고객(stayer)이 되는 것이고 관계유지의도가 부족하면 이탈의도가 발생하게 되어 다른 점포로 전환하는 전 환고객(switcher)이 된다고 주장하였다.

$\mathrm{Oh}(2000)$ 는 관계유지의도를 “장기적, 지속적, 계속 적으로 같은 브랜드를 구입하려는 의지를 갖는 상 태”라고 정의하였[21]. 결국, 기업은 고객과의 지속적 인 관계를 유지함으로써 재구매(재이용)의도, 긍정적 구전, 추천의도 등의 효과를 얻을 수 있다. 재의용의 도는 계속해서 현재의 관계를 유지하겠다는 의미인 데 고객의 재이용의도는 미래에도 서비스제공자를 반복하여 이용할 가능성이나 성과를 지속적으로 창 출시키는 중요한 요인이므로 마케팅에 있어서 가장 핵심적인 개념이다[3].

한편 구전(word of mouth)은 경험된 과정을 친구나 이웃 등에게 전달되고 바로 피드백이 일어나므로 다 른 매체를 통해 전달되는 것보다 강력한 신뢰효과를 가지고 있다[20]. 구전에는 긍정적으로 전달하려는 긍정적 구전의도와 주변에 추천하고자 하는 추천의 도가 있으며 이러한 의도들은 고객의 의사결정에 매 우 중요한 영향 요인이 되고 있다.

이들의 연구를 종합하여 본 연구에서의 관계유지 의도는 고객이 항공사 상위클래스 탑승 경험 후 해 당 항공사에 대한 고객의 긍정적 구전과 그에 따른 재이용의도, 추천의도로 측정하고자 한다.

\section{III. 조사설계}

\section{3-1. 연구모형 및 연구가설}

본 연구는 항공사 국제선 상위클래스를 이용하는 내국인 항공고객을 대상으로 물적-인적 서비스품질, 
고객들의 가치가 관계유지의도에 미치는 영향관계를 검증하고자 하였다. 이에 설정된 연구모형과 연구가 설은 다음과 같다.

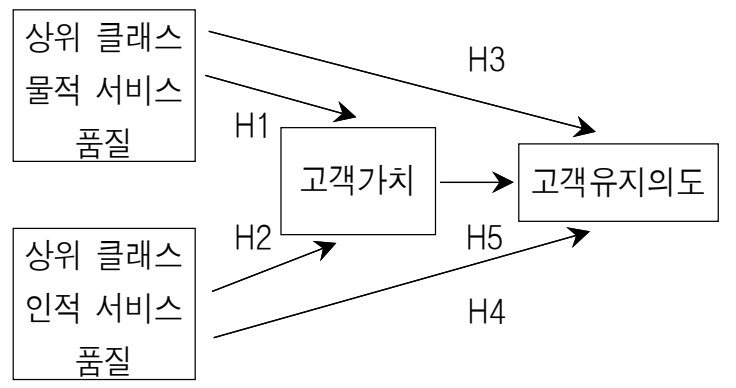

그림1. 연구모형

Fig. 1. Research Model of the Study

\section{3-1-1. 서비스품질과 고객가치와의 관계}

고객이 지각하게 되는 가치는 서비스품질과 가격 애 의해 영향을 받을 수 있으며(Chang \& Wildt, 1994; Dodds et al.,1999) 다수의 연구들은 서비스품질과 가 치간의 긍정적인 관계를 제시하고 있다. Kashyap과 Bojanic(2000)은 지각된 서비스품질과 가격에 의해서 가치가 형성되게 됨을 공식적으로 제시하고 있다. 또 한 PZB(1994)과 Grewal(1988), Zeithaml(1998)은 지각 된 서비스품질이 가치에 유의한 영향을 미치고 있음 을 통계적으로 입증하고 있다[22][23].

이러한 선행연구를 토대로 다음과 같은 연구가설 1 과 2 를 설정하였다.

가설1 : 상위클래스 물적 서비스품질은 고객가 치에 유의한 정(+)의 영향을 미칠 것이다.

가설2 : 상위클래스 인적 서비스품질은 고객가 치에 유의한 정(+)의 영향을 미칠 것이다.

\section{3-1-2. 서비스품질과 관계유지의도와의 관계}

Parasuraman, Berry \& Zeithaml(1988)은 고객들의 서비스품질에 대한 평가와 기업을 추천하려는 의도 사이에 강한 정 $(+)$ 의 상관관계가 있다고 제시하였 다. Cronin \& Tayler(1992)도 서비스품질과 후속적인
구매의도 간에 긍정적인 관계가 있음을 밝혀냈고 Boulding et, al(1993)의 연구에서도 서비스품질과 재 구매의도 및 추천의도 간의 강한 상관관계를 제시하 였다[22][23].

이러한 선행연구를 토대로 다음과 같은 연구가설 3 과 4 를 설정하였다.

가설3 : 상위클래스 물적 서비스품질은 관계유 지의도에 유의한 정(+)의 영향을 미칠 것이다.

가설4 : 상위클래스 물적 서비스품질은 관계유 지의도에 유의한 정(+)의 영향을 미칠 것이다.

\section{3-1-3. 고객가치와 관계유지의도와의 관계}

Kandampully \& Duddy(1999), Julian(1999), Swait \& Sweenty(2000), Sajeev(2001)는 고객이 상품과 서비스 를 이용한 후 지각하게 되는 가치는 긍정적인 구전과 재구매의도 및 그 기업을 추천하려는 의도에 큰 영향 을 미치는 심리적 변인이라고 하였으며 고객의 가치 가 고객의 만족과 긍정적 구전, 재구매의도, 추천의 도를 결정하는 주요요소로 인식되어진다고 하였다. 또한 박경호(2010)의 연구에서도 특급호텔 이용객의 고객가치의 각 차원들과 추천의도간에 긍정적인 영 향관계를 미치는 것으로 확인되었다[2].

이러한 선행연구를 토대로 다음과 같은 연구가설 5 를 설정하였다.

가설5 : 상위클래스 서비스품질에 대한 고객가 치는 고객의 관계유지의도에 유의한 정 $(+)$ 의 영향 을 미칠 것이다.

\section{3-2. 연구방법과 설문의 구성}

본 연구의 모집단은 인천국제공항을 이용하여 항 공사 국제선 상위클래스를 이용하는 내국인으로 한 정하였고 설문조사는 설문에 관한 취지와 기입방법 을 설명하여 주고 자기기입식 방법을 시행하였다.

본 연구의 조사기간은 2010년 11월 2일부터 2010 
년 11 월 30 일까지 인천국제공항의 출국장과 입국장 에서 이루어졌으며 총 200 부를 배포하여 180 의 유효 한 표본을 본 조사분석에 활용하였다.

분석방법으로는 측정변수들에 대한 신뢰도 검증 을 위해 상관관계분석에 의한 신뢰도분석을 실시하 였고 변인들 간의 타당성검증을 위해 탐색적 요인분 석을 실시하였다. 또한 가설검증을 위해 회귀분석을 실시하였다.

본 조사의 설문은 기존 선행연구를 바탕으로 항공 사 상위클래스 이용고객의 의견을 중심으로 작성되 었으며 다음 <표1>과 같이 구성하였다.

\section{표 1. 측정도구 및 설문의 구성}

Table 1. Measure factor \& questionnaire form

\begin{tabular}{|c|c|c|}
\hline 설문항목 & 변수 & 문항수 \\
\hline 일반적 특성 & $\begin{array}{c}\text { 성별, 연령, 학력, 월소득, 직업, } \\
\text { 연간해외여행횟수, 항공기이용목적, 주 } \\
\text { 이용노선, 이용 좌석등급 }\end{array}$ & 9문항 \\
\hline $\begin{array}{c}\text { 상위클래스 } \\
\text { 기내서비스품질 }\end{array}$ & $\begin{array}{l}\text { 물적서비스품질 } \\
\text { 인적서비스품칠 }\end{array}$ & 19문항 \\
\hline 출처 & \multicolumn{2}{|l|}{ 정익준(1992),한정혜(2004) } \\
\hline \multicolumn{2}{|r|}{ 고객가치 } & 3문항 \\
\hline 출처 & \multicolumn{2}{|c|}{ Lee,Yoon\&Lee(2007), Korda\&Milfelner(2009) } \\
\hline \multicolumn{2}{|r|}{ 관계유지의도 } & 3문항 \\
\hline 출처 & \multicolumn{2}{|l|}{ Berry\&Parasuraman(1996), Oh(2000) } \\
\hline
\end{tabular}

\section{VI. 실증분석결과}

\section{4-1. 표본의 일반적 특성}

본 연구에서 사용된 표본의 일반적 특성을 파악하 기 위하여 빈도분석을 실시하였으며, 그 결과는 <표 $2>$ 와 같다.

\section{표 2. 인구 통계학적 특성}

Table 2. Description of survey respondents

\begin{tabular}{|c|c|c|c|}
\hline 구분 & 내 용 & 빈도(명) & 비율(\%) \\
\hline \multirow{2}{*}{ 성별 } & 남 & 145 & 80.6 \\
\cline { 2 - 4 } & 여 & 35 & 19.4 \\
\hline
\end{tabular}

\begin{tabular}{|c|c|c|c|}
\hline \multirow{4}{*}{ 연령 } & 20 29세 & 9 & 5 \\
\hline & 30 39세 & 49 & 27.2 \\
\hline & 40 49세 & 67 & 37.2 \\
\hline & 50세이상 & 55 & 30.6 \\
\hline \multirow{3}{*}{ 학력 } & 고졸이하 & 23 & 12.7 \\
\hline & 대졸 & 127 & 70.6 \\
\hline & 대 학원이상 & 30 & 16.7 \\
\hline \multirow{5}{*}{ 월소득 } & 200만원이하 & 13 & 7.2 \\
\hline & 201 300만원 & 30 & 16.8 \\
\hline & 301 400만원 & 41 & 22.8 \\
\hline & 401 500만원 & 57 & 31.6 \\
\hline & 501만원이상 & 39 & 21.6 \\
\hline \multirow{5}{*}{ 직업 } & 전문직 & 66 & 36.7 \\
\hline & 사업 & 51 & 28.3 \\
\hline & 교직/공무원 & 38 & 21.1 \\
\hline & 사무직 & 15 & 8.3 \\
\hline & 기타 & 10 & 5.6 \\
\hline \multirow{3}{*}{$\begin{array}{l}\text { 연간해외 } \\
\text { 여행횟수 }\end{array}$} & 5회미만 & 33 & 18.3 \\
\hline & 5 10회 & 78 & 43.3 \\
\hline & 11번 이상 & 69 & 38.4 \\
\hline \multirow{4}{*}{$\begin{array}{c}\text { 항공기 } \\
\text { 이용목적 }\end{array}$} & 비즈니스 & 107 & 59.4 \\
\hline & 관광 & 38 & 21.1 \\
\hline & 친지방문 & 25 & 13.9 \\
\hline & 기타 & 10 & 5.6 \\
\hline \multirow{5}{*}{$\begin{array}{c}\text { 주 } \\
\text { 이용노선 }\end{array}$} & 일본/중국 & 104 & 57.8 \\
\hline & 아시아 & 45 & 25 \\
\hline & 미주 & 15 & 8.3 \\
\hline & 유럽 & 11 & 6.1 \\
\hline & 기타 & 5 & 2.8 \\
\hline \multirow{2}{*}{$\begin{array}{c}\text { 이용 } \\
\text { 좌석등급 }\end{array}$} & 국제선 비즈니스 & 163 & 90.6 \\
\hline & 국제선 퍼스트 & 17 & 9.4 \\
\hline
\end{tabular}

\section{4-2. 타당성 및 신뢰성 분석}

타당성이란 측정도구가 측정하고자 하는 것을 실 제로 정확하게 측정하고 있는지의 정도를 나타내는 것이다. 타당성 검증은 탐색적 요인분석을 실시하게 되는데 모든 측정변수는 구성요인을 추출하기 위해 서 주성분분석을 사용하였으며 요인적재량의 단순화 를 위하여 직교회전방식(varimax)을 채택하였다.

<표3>은 상위클래스 서비스품질차원인 물적 서비 스품질과 인적 서비스품질에 대한 요인분석의 결과 를 제시하고 있으며, 고유값(eigenvalue)이 1.0 이상인 각각 2 개와 3 개의 요인으로 추출되었고, 물적서비스 품질에 대한 전체분산설명력은 $61.382, \%$ 인적서비스 품질에 대한 전체분산설명력은 $75.559 \%$ 를 설명하고 있다. Cronbach's a값을 활용한 신뢰성 분석을 수행한 결과 모두 .7 이상으로 높게 나타났다. 
표 3 .상위클래스 기내서비스품질에 대한 타당성 및 신뢰성분석결과

Table 3. Exploratory factor \& reliability analysis of high-class in flight service quality

\begin{tabular}{|c|c|c|c|}
\hline & 요인 & 요인적재량 & 고유값 \\
\hline & FAC 1 (물적 서비스 & 품질) & \\
\hline & $\begin{array}{l}\text { 기내인테리어 및 전반적인 } \\
\text { 청결상태 }\end{array}$ & .825 & \\
\hline 유형성 & $\begin{array}{l}\text { 개인 AV시스템, 독서등 } \\
\text { 등의 작동 및 관리상태 }\end{array}$ & .821 & 3.547 \\
\hline & 기내 식음료 & .778 & \\
\hline & 기내 엔터테인먼트 & .745 & \\
\hline & 기내 좌석배치와 안락성 & .712 & \\
\hline & $\begin{array}{c}\text { 분산설명력(\%) } 31 . \\
\text { 신뢰도 } .845\end{array}$ & & \\
\hline & \begin{tabular}{|l|} 
기내면세품의 정확한 주분 \\
수령, 가격청구 및 물품전달
\end{tabular} & .812 & \\
\hline & $\begin{array}{l}\text { 질 높고 다양한 기내식의 } \\
\text { 정확한 서비스이행 }\end{array}$ & .809 & \\
\hline 신뢰성 & $\begin{array}{l}\text { 비상상황 발생시 정확하고 } \\
\text { 신속한 안내절차 이행 }\end{array}$ & .785 & 2.412 \\
\hline & $\begin{array}{l}\text { 정확한 항공기 출도착 시간 } \\
\text { 안내절차 이행 }\end{array}$ & .752 & \\
\hline & 승무원의 용모와 복장상태 & .701 & \\
\hline & $\begin{array}{r}\text { 분산설명력(\%) } 30 . \\
\text { 전체분산설명력(\%) } 6 \\
\text { 신뢰도 .776 }\end{array}$ & 124 & \\
\hline & $\begin{array}{r}\mathrm{KMO}=0.802(>0 \\
\text { Bartlett구형성 검증 } \quad X^{2}=1245\end{array}$ & $.65(p=0.000)$ & \\
\hline & FAC 2 (인적 서비스 & :품질) & \\
\hline & 승무원의 인사태도 & .877 & \\
\hline 반응성 & 승무원의 적극적인 태도 & .862 & 3.102 \\
\hline & $\begin{array}{l}\text { 고객에게 서비스 제공에 } \\
\text { 대한 정보 }\end{array}$ & .846 & \\
\hline & $\begin{array}{r}\text { 분산설명력(\%) } 22 . \\
\text { 신뢰도 .822 }\end{array}$ & & \\
\hline & $\begin{array}{l}\text { 승무원의 항공기 전반에 대 } \\
\text { 한 지식 }\end{array}$ & .787 & \\
\hline 확실성 & $\begin{array}{l}\text { 고객 질문에 대한 정확한 } \\
\text { 답변과 스킬보유 }\end{array}$ & .754 & 2.085 \\
\hline & 승무원의 세련된 태도, 화법 & .731 & \\
\hline & $\begin{array}{r}\text { 분산설명력(\%) } 30 . \\
\text { 신뢰도 .776 } \\
\end{array}$ & & \\
\hline & $\begin{array}{l}\text { 승무원의 고객 입장에서 } \\
\text { 서비스 제공 }\end{array}$ & .835 & \\
\hline 공감성 & $\begin{array}{l}\text { 객의 불만사항 경청과 } \\
\text { 즉각적 수용 }\end{array}$ & .816 & 1.457 \\
\hline & 고객에 대한 인간적 관심 & .798 & \\
\hline & $\begin{array}{c}\text { 분산설명력(\%) } 22 . \\
\text { 전체분산설명력(\%) } \\
\text { 신뢰도 } 854\end{array}$ & $\begin{array}{l}521 \\
75.559\end{array}$ & \\
\hline & $\begin{array}{r}\mathrm{KMO}=0,843(>0 \\
\text { Bartlett구형성 검증 } \dot{X}^{2}=1322\end{array}$ & $.74(p=0.000$ & \\
\hline
\end{tabular}

<표4>에서 상위클래스 서비스품질에 대한 고객 가치를 구성하는 측정척도의 전체분산설명력은 58.745 로 3 개 문항 모두 1 개의 요인에 적재되어 단 차원성(uni-dimention)을 가지는 것으로 나타났다. 또한 Cronbach's a값을 활용한 신뢰성 분석을 수행 한 결과 고객가치의 신뢰도는 .9이상으로 높게 나 타났다

표 4. 고객가치에 대한 타당성 및 신뢰성분석결과 Table 4. Exploratory factor \& reliability analysis of customer value

\begin{tabular}{|c|c|c|}
\hline 요인 & 요인적재량 & 고유값 \\
\hline \multicolumn{3}{|c|}{ FAC1(고객가치) } \\
\hline 지불비용에 대한 가격의 가치 & .831 & \multirow{3}{*}{2.475} \\
\hline 지속적인 높은 서비스가치 & .812 & \\
\hline 상위클래스탑승에 대한 상징적가치 & .764 & \\
\hline \multicolumn{3}{|c|}{$\begin{array}{c}\text { 분산설명력(\%) } 58.745 \\
\text { 전체분산선명력(\%) } 58.745 \\
\text { 신뢰도 } .913 \\
\end{array}$} \\
\hline $\begin{array}{r}\mathrm{KMO}=0.848 \\
\text { Bartlett구형성 검증 } \quad X^{2}=121\end{array}$ & $.58(\mathrm{p}=0$ & \\
\hline
\end{tabular}

<표5>에서 상위클래스 서비스품질에 대한 고객 들의 관계유지의도를 구성하는 측정척도의 전체분 산설명력은 65.452 로 3 개 문항 모두 1 개의 요인에 적재되어 단차원성(uni-dimention)을 가지는 것으로 나타났다. 또한 Cronbach's a값을 활용한 신뢰성 분 석을 수행한 결과 고객가치의 신뢰도는 .9이상으로 높게 나타났다

표 5. 관계유지의도에 대한 타당성 및 신뢰성분석결과 Table 4. Exploratory factor \& reliability analysis of relationship retention intention

\begin{tabular}{|c|c|c|}
\hline 요인 & 요인적재량 & 고유값 \\
\hline \multicolumn{3}{|c|}{ FAC1(관계유지의도) } \\
\hline 이 항공사에 대해 긍정적으로 말할것임 & .984 & \multirow{3}{*}{1.984} \\
\hline 이 항공사를 다시 이용할 것임 & .942 & \\
\hline 이 항공사를 주변에 추천하고 싶음 & .841 & \\
\hline \multicolumn{3}{|c|}{$\begin{array}{c}\text { 분산설명력(\%) } 65.452 \\
\text { 전채분산설명력(\%) } 65.452 \\
\text { 신뢰도 } .819\end{array}$} \\
\hline \multicolumn{3}{|c|}{$\begin{array}{c}\mathrm{KMO}=0.845(>0.6) \\
\text { Bartlett구형성 검증 } \dot{X}^{2}=1227.58(p=0.000)\end{array}$} \\
\hline
\end{tabular}

4-3. 가설검증

4-3-1. 가설 1 의 검증 
상위클래스의 물적 서비스품질이 고객가치에 미 치는 영향을 분석한 결과는 <표6>와 같다.

먼저, R2값이 0.421 로서 회귀모형의 설명력이 $42.1 \%$ 로 나타났으며 $\mathrm{F}$ 값은 67.038 로서 유의수준 $0.1 \%$ 에서 유의한 것으로 나타났다. 독립변수들의 영향력 을 보면 유형성은 t값이 5.674, 신뢰성은 t값이 5.554로 서 각각 유의수준 $0.1 \%$ 에서 고객가치에 정 $(+)$ 의 영향 을 미치고 있었다. 이들 변수의 상대적 영향력은 유형 성 $(\mathrm{B}=.368)$, 신뢰성 $(\mathrm{B}=.364)$ 순으로 나타났다.

표 6. 상위클래스 물적 서비스품질이 고객가치에 미치는 영향 분석결과

Table 6. The results of regression analysis on the impact which physical service quality have on customer value

\begin{tabular}{|c|c|c|c|c|}
\hline \multirow{2}{*}{ 모형 } & 비표준화계수 & 표준화계수 & \multirow{2}{*}{$\mathrm{t}$} & $\mathrm{p}$ \\
\cline { 2 - 3 } & $\mathrm{B}$ & $B$ & & \\
\hline (상수) & .346 & & 4.208 & .000 \\
\hline 유형성 & .397 & .368 & $5.674 * \star \star$ & .000 \\
\hline 신뢰성 & .385 & .364 & $5.554 * * \star$ & .000 \\
\hline \multicolumn{2}{|c|}{$\mathrm{R} 2=.402$ 수정된 $\mathrm{R} 2=.421 \mathrm{~F}=67.038 \quad \mathrm{p}$-value $=0.000$} \\
\hline
\end{tabular}

$*: \mathrm{p}<.05 * *: \mathrm{p}<.01 * * *: \mathrm{p}<.001$

\section{4-3-2. 가설 2의 검증}

상위클래스의 인적 서비스품질이 고객가치에 미 치는 영향을 분석한 결과는 <표7>과 같다.

먼저, R2값이 0.478 로서 회귀모형의 설명력이 $47.8 \%$ 로 나타났으며 $\mathrm{F}$ 값은 78.532 로서 유의수준 $0.1 \%$ 에서 유의한 것으로 나타났다. 독립변수들의 영 향력을 보면 반응성은 t값이 2,287로서 유의수준 5\% 에서 확실성은 t값이 4.245 로서 유의수준 $0.1 \%$ 에서 공감성은 t값이 3.342 로서 유의수준 $1 \%$ 에서 고객가 치에 정(+)의 영향을 미치고 있었다. 이들 변수의 상 대적 영향력은 확실성이 고객가치에 가장 큰 영향을 미치고 있었고 공감성, 반응성 순으로 나타났다.

표 7.상위클래스 인적 서비스품질이 고객가치에 미치는 영향 분석결과

Table 7. The results of regression analysis on the impact which human service quality have on customer value

\begin{tabular}{|c|c|c|c|c|}
\hline \multirow{2}{*}{ 모형 } & 비표준화계수 & 표준화계수 & \multirow{2}{*}{$\mathrm{t}$} & \multirow{2}{*}{$\mathrm{p}$} \\
\cline { 2 - 3 } & $\mathrm{B}$ & $\mathrm{B}$ & & \\
\hline (상수) & .297 & & 1.478 & .152 \\
\hline 반응성 & .201 & .178 & $2.287 \star$ & .024 \\
\hline 확실성 & .369 & .354 & $4.245 * \star *$ & .000 \\
\hline
\end{tabular}

\begin{tabular}{|c|c|c|c|c|}
\hline 공감성 & 268 & .253 & $3.342 \star \star$ & .001 \\
\hline \multicolumn{5}{|c|}{$\mathrm{R} 2=.474$ 수정된 $\mathrm{R} 2=.478 \mathrm{~F}=78.532 \quad \mathrm{p}$-value $=0.000$} \\
\hline \multicolumn{5}{|c|}{$*: \mathrm{p}<.05 * *: \mathrm{p}<.01 * * *: \mathrm{p}<.001$} \\
\hline
\end{tabular}

상위클래스의 물적 서비스품질이 관계유지의도에 미치는 영향을 분석한 결과는 <표8>과 같다.

먼저, $\mathrm{R}^{2}$ 값이 0.310 로서 회귀모형의 설명력이 $31 \%$ 로 나타났으며 F값은 50.721로서 유의수준 0.1\% 에서 유의한 것으로 나타났다. 독립변수들의 영향력 을 보면 유형성은 t값이 5.120, 신뢰성은 t값이 3.854 로서 유의수준 $0.1 \%$ 에서 관계유지의도에 정 $(+)$ 의 영향을 미치고 있었다. 이들 변수의 상대적 영향력 은 유형성이 관계유지의도에 가장 큰 영향을 미치고 있었고 신뢰성 순으로 나타났다.

표 8. 상위클래스 물적 서비스품질이 관계유지의도에 미치는 영향 분석결과

Table 8. The results of regression analysis on the impact which physical service quality have on relationship retention intention

\begin{tabular}{|c|c|c|c|c|}
\hline \multirow{2}{*}{ 모형 } & 비표준화계수 & 표준화계수 & \multirow{2}{*}{$\mathrm{t}$} & $\mathrm{p}$ \\
\cline { 2 - 3 } & $\mathrm{B}$ & $B$ & & \\
\hline (상수) & 1.047 & & 4.208 & .000 \\
\hline 유형성 & .425 & .346 & $5.120 * * *$ & .000 \\
\hline 신뢰성 & .288 & .254 & $3.854 * * *$ & .000 \\
\hline \multicolumn{2}{|c|}{$\mathrm{R} 2=.302$ 수정된 $\mathrm{R} 2=.310 \mathrm{~F}=50.721 \quad \mathrm{p}$-value $=0.000$} \\
\hline
\end{tabular}

\section{4-3-4. 가설 4의 검증}

상위클래스의 인적 서비스품질이 관계유지의도에 미치는 영향을 분석한 결과는 <표 $9>$ 와 같다.

먼저, R2값이 0.425 로서 회귀모형의 설명력이 $42.5 \%$ 로 나타났으며 $\mathrm{F}$ 값은 65.064 로서 유의수준 $0.1 \%$ 에서 유의한 것으로 나타났다. 독립변수들의 영 향력을 보면 반응성은 t값이 2,541, 확실성은 2.809 , 공감성은 3.452 로서 모두 유의수준 $1 \%$ 에서 관계유지 의도에 정 $(+)$ 의 영향을 미치고 있었다.

이들 변수의 상대적 영향력은 공감성 $(\mathrm{B}=.261)$ 이 관계유지의도에 가장 큰 영향을 미치고 있었고 확실 성, 반응성 순으로 나타났다. 
표 9. 상위클래스 인적 서비스품질이 관계유지의도에 미치는 영향 분석결과

Table 9. The results of regression analysis on the impact which human service quality have on relationship retention intention

\begin{tabular}{|c|c|c|c|c|}
\hline \multirow{2}{*}{ 모형 } & 비표준화계수 & 표준화계수 & \multirow{2}{*}{$\mathrm{t}$} & $\mathrm{p}$ \\
\cline { 2 - 3 } & $\mathrm{B}$ & $B$ & & \\
\hline (상수) & .678 & & 3.475 & .000 \\
\hline 반응성 & .256 & .223 & $2.541 * \star$ & .008 \\
\hline 확실성 & .242 & .238 & $2.809 * \star$ & .005 \\
\hline 공감성 & .268 & .261 & $3.452 * \star$ & .001 \\
\hline \multicolumn{2}{|c|}{$\mathrm{R} 2=.402$ 수정된 $\mathrm{R} 2=.425 \mathrm{~F}=65.064 \quad \mathrm{p}$-value $=0.000$} \\
\hline
\end{tabular}

*: $\mathrm{p}<.05 * *: \mathrm{p}<.01 * * *: \mathrm{p}<.001$

4-3-5. 가설 5의 검증

상위클래스 고객의 가치가 관계유지의도에 미치 는 영향을 분석한 결과는 <표10>과 같다.

먼저, R2값이 0.498 로서 회귀모형의 설명력이 $49.8 \%$ 로 나타났으며 F 값은 210.321 로서 유의수준 $0.1 \%$ 에서 유의한 것으로 나타났다. 독립변수들인 고 객가치는 t값이 15.815 로서 유의수준 $0.1 \%$ 에서 관계 유지의도에 정(+)의 영향을 미치고 있었다.

표 10.상위클래스 고객가치가 관계유지의도에 미치는 영향 분석결과

Table10. The results of regression analysis on the impact which customer value have on relationship retention intention

\begin{tabular}{|c|c|c|c|c|}
\hline \multirow{2}{*}{ 모형 } & 비표준화계수 & 표준화계수 & \multirow{2}{*}{$\mathrm{t}$} & $\mathrm{p}$ \\
\cline { 2 - 4 } & $\mathrm{B}$ & $B$ & & \\
\hline (상수) & 1.371 & & 8.478 & .000 \\
\hline 고객가치 & .675 & .701 & $15.815 * * *$ & .000 \\
\hline \multicolumn{2}{|l|}{$\mathrm{R} 2=.477$ 수정된 $\mathrm{R} 2=.498 \mathrm{~F}=210.321 \quad \mathrm{p}$-value $=0.000$} \\
\hline
\end{tabular}

\section{V. 결 론}

오늘날 세계 항공 산업은 항공노선의 확대, 운항 횟수의 증대, 항공고객의 다양한 욕구에 부응하기 위 하여 전략적 제휴방식으로 글로벌화 되면서 다각도 의 서비스 경쟁전략 체계를 구축하고 있다. 특히 항 공사간의 생존전략으로 신 경영도입, 구조조정, 신
마케팅 전략수립, 다국적 항공사간의 전략적 제휴 등 경영전반에 걸쳐 다각적인 방법들이 모색되고 있다. 이 중 항공기 상위클래스 시장의 중요성이 점차 커지 고 있으며 이에 따라 세계 항공 산업은 상위클래스의 효율적이고 차별화된 기내 서비스품질 제공에 주력 하고 있다.

이러한 환경을 바탕으로 본 연구자는 항공 산업에 서 항공기 상위클래스 서비스품질과 상위클래스를 이용하는 고객들이 자신의 지불한 가격에 대해 만족 할 만한 가치를 얻었는지, 그리고 이들이 해당 항공 사의 관계를 지속적으로 관계를 유지할 것인지에 대 한 문제를 중요하게 인지, 검토하게 되었다.

따라서 본 연구는 항공기 상위클래스 기내 서비스 품질을 물적서비스, 인적서비스요인으로 나누고 이 에 대한 고객가치 및 관계유지의도와의 영향 관계를 분석하였는데 주요 분석 결과는 다음과 같다.

첫째, 상위클래스 물적 서비스품질요인과 인적서 비스품질요인은 고객의 가치와 관계유지의도에 긍정 적인 영향을 미치는 것으로 나타났다. 전반적인 기내 인테리어 및 청결 상태와 기내좌석의 편안함과 안락 함, 기내 식음료, 엔터테인먼트 이용 그리고 승무원 의 항공기에 대한 높은 지식과 고객의 입장에서 서비 스를 제공하며 인간적인 관심을 가질수록 상위클래 스 고객이 느끼는 가치는 긍정적으로 나타났다. 즉, 고객이 지불하는 직접화폐 가치인 서비스 가격으로 부터 얻어지는 편익에 영향을 주게 되어 고객들이 지 각하게 되는 가치는 커지게 된다고 할 수 있다. 또한 이러한 서비스품질요인들은 고객들이 해당 항공사를 다시 이용하게 되고 타인에게 긍정적으로 구전하며 주변에 추천하는 것으로 나타났다.

둘째, 상위클래스 고객들이 지각하는 가치는 해당 항공사에 대한 관계유지의도에 긍정적인 영향을 미 치는 것으로 나타났다. 이는 상위클래스 이용 고객이 상위클래스 서비스 결과를 기대하고 비용을 지불한 후 실제 그 기대수준을 만족하는 서비스를 받았다고 느낄 때 해당 항공사에 대한 관계유지의도는 높아지 게 됨을 의미한다.

이와 같은 결과로 상위클래스를 이용하는 고객들 에게는 최신 항공기 도입과 이용고객 1 명당 좌석 면 적을 넓게 하는 편리한 객실 공간, 최첨단 기내설비, 
지속적인 기내설비 업그레이드, 상위클래스 고객들 의 요구에 맞춘 기내 식음료 등의 물적 서비스제공의 향상이 더욱 더 필요하며 상위클래스를 담당하는 승 무원은 전문성을 더욱 더 갖추고 약속된 서비스를 신 속 정확하게 수행함과 동시에 고객들에 대한 개별적 인 관심과 배려와 같은 인적 서비스품질의 향상이 더 욱 더 요구된다.

항공기 상위클래스 서비스 경쟁력제고를 위해서 는 전략적 제휴, 고객정보의 데이터베이스화, 마일리 지 활용 서비스 강화, 상위클래스 주요 타겟인 남성 비즈니스고객들에 대한 프로모션 등 기존 서비스와 는 다른 차별화된 전략적 마케팅이 절실하며 기내서 비스가 정체되지 않는 가격 그 이상의 가치를 줄 수 있어야 할 것이다. 항공사의 무한 경쟁 서비스 시대 를 맞이하여 생존을 위하여 조직의 질을 향상시키며 고객감동의 실현을 위해 승무원 서비스 교육에 대한 투자와 정성이 요구된다.

이러한 시사점에도 불구하고 본 연구의 한계는 첫 째, 조사대상이 내국인에게만 한정이 되어 국내외 고 객과 국내외 항공사를 비교연구하지 못한 점이다. 향 후에는 조사대상을 상위클래스 모든 이용고객과 국내 외 항공사를 포함하여 연구를 진행한다면 좀 더 심층 적이고 깊이 있는 연구가 될 것이다. 또한 내국인과 외국인 고객의 인식 차이 연구도 의미가 있을 것이다.

둘째, 비행거리에 따른 비행시간 인식차이 연구와 셋째, 본 연구의 조사 대상의 대부분이 남성이 차지 하였는데 최근 여성의 사회진출과 참여가 활발해지 고 소비의 주체이자 경제활동을 선도하는 주체로서 여성이 부각되고 있는 점을 볼 때 후속 연구에서는 효과적인 여성마케팅을 강화할 수 있는 연구가 필요 하다.

마지막으로 상위클래스 서비스품질차원과 고객가 치, 관계유지의도 이외에 추가적인 변수를 통한 분석 과 상위클래스 서비스품질과 결과변수간의 관계에 영향을 미치는 조절변수를 추가한 연구를 시행한다 면 더욱 많은 시사점이 도출될 것으로 사료된다.

\section{참 고 문 헌}

[1] 문희정(2010) 항공사 객실 승무원 상위클래스 교육훈련 전이에 대한 연구, 한양대학교 대학원 석사학위논문.

[2] 박경호(2010), 특급호텔의 서비스품질과 고객가치, 고객만족, 추천의도에 관한 실증적 연구, 관광연구, 25(5), pp.209-229.

[3] 박선희(2005), 브랜드개성이 소비자브랜드관계결 과인 재방문의도에 미치는 영향, 경희대학교 대 학원 석사학위논문.

[4] 변정우·서현숙(2010). 지역 특1급 호텔의 다차원적 서 비스편의성과 고객가치, 고객만족, 행동의도와의 관 계에 관한 연구, 호텔경영학연구, 19(1), pp. 55-72.

[5] 유연옥(2007), 항공기 캐빈클래스 서비스속성 및 만족도 연구, 한양대학교 대학원 석사학위논문.

[6] 윤재석(2006). 상위클래스 항공좌석 수요 결정 요 인 분석, 경기대학교 대학원 박사학위논문.

[7] 오주희(2002), 국적항공사의 서비스품질평가, 한양 대학교 대학원 석사학위논문.

[8] 정익준(1992), 우리나라 항공사의 국제선 여객운송 서비스마케팅 전략에 관한 연구, 부산대학교 대 학원 박사학위논문.

[9] 차민영(2009) 항공사 상위클래스 서비스품질과 지 각된 서비스가치에 따른 고객만족과의 관계연구, 경기대학교 대학원 석사학위논문.

[10] 한상린(2004), 레스토랑 서비스품질이 고객유지와 구 전에 미치는 영향, 마케팅관리연구, 19(1), pp. 29-46.

[11] 한정혜(2004), 객실 서비스품질이 고객충성도에 미치는 영향 연구, 경기대학교 석사학위논문.

[12] 한국항공진흥협회 www.airtransport.or.kr

[13] 아시아나항공 www.flyasiana.com

[14] 대한항공 http://kr.koreanair.com

[15] 매일경제, 2011.

[16] Bolton, R. N \& Drew, J. H(1991). "Effects of price, brand, and store information on buyers products evaluations", Journal of Marketing Research, 28(3), pp.307-319.

[17] Dodds, W. B., Monroe, K. B \& Grewal(1991) "Effects of price, brand and store information on buyers" product evaluation, Journal of Marketing Research, 28(3), pp.307-319.

[18] Korda, A. P. \& Milfelner. B(2009), The importance of perceived value in evaluating hotel guest satisfaction: The case of Slovenia, 21(1), pp.73-94. 
[19] Liou, J. H. \& Tzeng, G. H.(2007), "A non-additive model for evaluation service quality", Journal of Air Transport Management, 13(3), pp.131-138.

[20] Mckennna, R.(1991), Relationship Marketing: Successful Strateges for the age of the customer, Addison-Wesley Pub., Co.

[21] Oh, H.(2000). Diner's Perceptions of quality, value and satisfaction, The Cornell HRA Quartly, 41(3), pp. 58-66.

[22] Parasuraman, A., Zeithaml, V. A., \& Berry, L. L.(1985). Conceptual model of service quality and its implications for future research. Journal of Retailing, 64(1), pp.12-40.

[23] Parasuraman, A., Zeithaml, V. A., \& Berry, L. L(1988), SERVQUAL: a multiple-item scale for measuring consumer perceptions of service quality. Journal of Retailing, 64(1), pp12-40.

[24] Petrick, J. F.(2002), "Development of a multi-dimensional scale for measuring the perceived value of a service, Journal of Leisure Research, 34(2), pp.119-134.

[25] Sweeney, J. C. \& Soutar, G. N.(2001). Consumer perceived value: the development of a multiple item scale. Journal of Retailing, 77(2), pp. 203-222.

[26] Ulaga, W. \& Chacour, S(2001). Measuring Customer-Perceived Value in Business Markets. Industrial Masrketing Management. 30, pp. 525-540.

\section{윤 선 영 (尹善瑛)}

1988년 2월 : 홍익대학교 문학사(영어교육)

1990년 2월 : 홍익대학교 교육학 석사(영어교육)

1995년 10월 : The University of Birmingham 관광정책 경영학 석사

1999년 2월 : 경기대학교 경영학박사

2003년 3월 현재 : 경기대학교 관광대학 이벤트학과, 관광전문대학원 여행항공크루즈 전공 부교수 관심분야 : 관광경영, 마케팅커뮤니케이션, 산업전시 박람회 